\title{
BYPASSING THE BUST: \\ THE STABILITY OF UPSTATE NEW YORK'S HOUSING MARKETS DURING THE RECESSION
}

\author{
Jaison R. Abel and Richard Deitz
}

\section{INTRODUCTION}

The United States experienced a sizeable boom in real estate activity between 1998 and 2006, followed by a sharp contraction. Home prices rose over 8 percent per year, on average, between 2000 and 2006, but have been sinking at an average annual rate of 4 percent more recently. ${ }^{1}$ Indeed, headlines in places such as California, Arizona, and Florida paint a stark picture of the boom-bust cycle experienced in many parts of the country. For example, home prices have plunged by more than half since 2006 in places such as Merced, Stockton, and Modesto in California. Perhaps somewhat surprisingly, though, many parts of the country are not experiencing such dramatic declines in housing prices, with many places registering price increases during the national downturn. The metropolitan areas of upstate New York epitomize this trend. Despite long-term weak economic growth and population loss in Buffalo, for example, home prices have risen in the metropolitan area continually over the past several years, without decline, and this housing market ranks in the top 10 percent of metropolitan areas in terms of home price appreciation so far in 2009.

1 Four-quarter price change in the Federal Housing Finance Authority (FHFA) “All Transactions” house price index as of Q2-2009. This house price index is based on conventional and conforming loans and includes both repeat purchases and refinances. A major advantage of the FHFA house price index over the widely cited S\&P/Case-Shiller house price index is its broader geographic coverage, which we rely on extensively in our analysis. The FHFA index is available for 383 metropolitan areas/divisions, while the S\&P/Case-Shiller index covers only the 20 largest metropolitan areas. For several reasons, the FHFA index tends to differ from the more volatile S\&P/Case-Shiller index. See Calhoun (1996) and Leventis (2008) for more details about the construction of the FHFA house price index and major differences between it and the S\&P/Case-Shiller house price index. 
These differences in the pattern of housing market activity during the most recent housing cycle have had significant implications for the economic performance of regions during the recession. A decline in housing activity reduces employment and incomes in housing related industries such as construction, real estate, and retail. Moreover, declines in household wealth related to falling housing values reduces consumer spending, which further dampens regional economic activity. Because the fallout from a decline in housing activity can be severe, many parts of the country that are avoiding a housing bust have performed better during the recession than many of the most rapidly growing metropolitan areas in the country. These regions have tended to be places that did not have particularly strong economic performance over the past decade, but they are now benefiting from a more stable economic environment. In addition, especially where more risky and leveraged home buying occurred, the decline in home values is leading to defaults and foreclosures, further dampening economic activity. Like many of its peer mid-sized slower growth cities, the metropolitan areas in upstate New York have largely been insulated from many of these deleterious consequences.

In this edition of Second District Highlights, we assess the performance of upstate New York's housing markets during the most recent residential real estate cycle. We analyze the extent to which the region has been insulated from the boom-bust pattern experienced in many parts of the country, and examine the pattern of real estate activity for the region compared to metropolitan areas across the country. We also examine the magnitude of lending activity in the riskiest segment of the residential mortgage market, so called "nonprime" mortgages, and compare the penetration and performance of these loans in the region to the nation. We find that upstate New York's housing markets have 
remained relatively stable during the recession, with many of the region's metropolitan areas outperforming the nation. In fact, most of the metropolitan areas in the region had at least a modest housing boom with no subsequent bust. We also find that there were fewer nonprime loans originated in the region, and that among those loans that were made, upstate's loan performance was better than average. These dynamics help explain the stability of upstate New York's housing markets during the recession.

\section{THE HOUSING BOOM IN THE U.S. AND IN UPSTATE NEW YORK}

The U.S. experienced a significant housing boom that began in the mid-1990s and lasted until 2006. Sales of existing homes rose significantly between 1995 and 2000, followed by an even sharper increase in activity between 2000 and 2005 (Chart 1). The level of sales peaked in 2005, followed by a sharp decline of activity between 2005 and 2008. By contrast, residential real estate activity across upstate New York was relatively flat throughout this entire period. ${ }^{2}$ Indeed, while existing home sales grew by more than 75 percent between 1995 and 2005 in the United States, sales grew by only 15 percent in upstate New York. Notably, while sales activity in the region was well below the nation during this period, the decline that followed was less pronounced for upstate New York. Between 2005 and 2008, home sales declined by roughly 30 percent in the U.S., while declining only 10 percent in upstate New York.

At the same time that existing sales were rising in the nation, home building was occurring at a rapid pace. As a measure of new home construction, the growth of residential building permits is illustrated in Chart 2, where the number of permits issued

2 The aggregate upstate New York index is calculated using data on existing single-family home sales in the nine major metropolitan areas in the region: Albany, Binghamton, Buffalo, Elmira, Glens Falls, Ithaca, Rochester, Syracuse, and Utica. Source: National Association of Realtors and Moody's Economy.com. 
is scaled by the population. ${ }^{3}$ On a per capita basis, the level of new home building activity in upstate New York was roughly half that of the nation throughout the 1990s and 2000s, in large part because of the region's slow population loss which dampened the need for new housing. The pace of growth in building permits increased in the U.S. during the 1990s, and gained significant upward momentum between 2001 and 2005. While the level of activity was lower, the pace of growth in building permits issued in upstate New York mirrored that of the nation between 1995 and 2002, as the slope in the lines is roughly parallel over this period. As the national pace of building accelerated beginning in 2002, however, new construction began a steady decline in upstate New York. Further, as the pace of building in the U.S. fell sharply beginning in 2006, upstate New York's rate of decline, while significant, was not nearly as rapid as experienced in the nation as a whole.

Just as the boom in the quantity of home sales and building activity was muted in upstate New York, home price appreciation also tended to be more limited in the region (Chart 3). ${ }^{4}$ The rate of appreciation in the region was well below the nation until early 2007, and home price declines were registered in 1995, 1997, and 2000. During the period of most rapid appreciation in the U.S., 2004-2006, the pace of appreciation in upstate New York also rose significantly, although it held below the nation. The rate of home price appreciation declined dramatically in the U.S. beginning in 2006. In 2007 and

3 We examine building permits for residential construction of new buildings, as opposed to new home sales, since new home sales data are not available at the regional level. Non-residential permits are not included in these statistics. Source: Bureau of the Census.

4 To construct our aggregate upstate New York house price index, we follow the same methodology used by the FHFA to compile its national house price index. Specifically, we set the index equal to 100 in Q1-1995 and adjust the index each successive quarter based on the weighted average quarterly price change for the 9 upstate metropolitan areas, with the weights based on the contemporary share of oneunit detached properties in each metropolitan area. See http://www.fhfa.gov/ for more detail. 
2008, upstate's rate of price growth outpaced the U.S., and prices continued to climb into 2009, despite a decline in home values of nearly 4 percent in the nation as a whole during the first half of 2009.

These differences in the pattern of home price appreciation between upstate New York and the U.S. as a whole are significant. However, as is often said, "all real estate is local"- the nation's housing market is not a single unit, but rather is a collection of a diverse set of experiences of regional markets. As such, we next examine the regional dimension of house price dynamics in more detail.

\section{HOUSE PRICE APPRECIATION ACROSS METROPOLITAN AREAS}

The pattern of house price appreciation leading up to the peak in 2006, and the subsequent decline since, varies considerably among metropolitan areas across the country. In general, however, places where prices increased the most tended to experience the most significant declines. This negative correlation is illustrated in Chart 4, which plots the average annual increase in home prices for all metropolitan areas in the country over the 2000-2008 period. Along the horizontal axis, we measure the average annual increase in home prices during between 2000 and 2006, and along the vertical axis, we measure the average annual increase between 2006 and 2008. We classify metropolitan areas into four categories based on where rates of appreciation fell relative to the U.S. average during these periods. In the lower right quadrant are "Boom, Bust" metropolitan areas, where home prices increased faster than the average U.S. annual rate of 8.3 percent between 2000 and 2006, and fell at a more rapid pace than the U.S. rate of -0.3 percent between 2006 and 2008. In the opposing quadrant in the upper left are "Modest or No Boom, No Bust" metropolitan areas, where prices increased less than the 
national rate between 2000 and 2006, but did not fall as quickly as the nation between 2006 and 2008. In the upper right quadrant are "Boom, No Bust" metropolitan areas where prices increased more rapidly than average during both periods, and in the lower left quadrant are "Modest or No Boom, Bust" metropolitan areas where prices increased less than the national average rate during both periods.

Looking at the metropolitan areas appearing in the lower right quadrant, places with the most rapid price appreciation in the earlier period tended to experience the sharpest declines over the later period. Geographic clustering is also apparent, with 14 of the 25 most rapidly growing markets in that quadrant located in California, and 10 in Florida. Each of these metropolitan areas experienced around 15 to 20 percent price appreciation per year, on average. Once prices began to decline in 2006, metro areas in this quadrant experienced very large price drops, averaging around 15-20 percent per year, with Merced, Stockton, and Modesto all declining at a more than a 20 percent average annual rate.

Perhaps somewhat surprisingly, most metropolitan areas in the country actually experienced more moderate increases than the nation as a whole between 2000 and 2006. In fact, 249 of the 383 metropolitan areas tracked by the FHFA had increases below the U.S. rate of 8.1 percent during the boom. Because outsized increases tended to occur in large, highly populous metropolitan areas, the average rate for the nation as a whole strongly reflects the experience of these places. Most metropolitan areas also performed better than the 0.3 percent rate of decline for the nation over the 2006-2008 period. Indeed, 220 metropolitan areas experienced below average house price appreciation between 2000-2006, but performed better than the nation between 2006-2008, and fall 
into the "Modest or No Boom, No Bust" category. Most upstate metropolitan areas are in this group, including Buffalo, Rochester, Syracuse, Utica, Binghamton, and Elmira (see Table 1 for precise figures).

The worst of the performing metropolitan areas had lower rates of appreciation than the U.S. during both periods. These 29 "Modest or No Boom, Bust" metropolitan areas appear in the lower left quadrant. Within this quadrant, 10 of the 11 worst home price declines over the 2006-2008 period were all in Michigan. The best performing metropolitan areas had faster than average house price appreciation in both periods, appearing in the upper right quadrant. Examples of metropolitan areas included in this group are Honolulu and Virginia Beach, together with three upstate New York metropolitan areas-Albany, Glens Falls, and Ithaca (see Table 1 for precise figures). Interestingly, Glens Falls and Ithaca were among the top 10 best performing metropolitan areas in this quadrant.

The geographic concentration of these different groups is apparent in the Map. "Boom, Bust" metropolitan areas are clearly clustered in three regions of the country: along the west coast, including California, Nevada, Oregon, and Arizona; in Florida; and along the Northeast corridor, spanning Maryland, Washington D.C., Rhode Island, Delaware, Massachusetts, Connecticut, and New Hampshire. Places classified as "Moderate or No Boom, Bust” metropolitan areas cluster along the Great Lakes regions of Ohio, Michigan, Indiana, and Illinois, and Minnesota, and dot Colorado and Arkansas. Metropolitan areas in the "Modest or No Boom, No Bust" category populate much of the country, while those in the "Boom, No Bust" category appear all along the eastern coastline, and in Virginia, eastern Pennsylvania and upstate New York; in Washington, 
Idaho, and Oregon; in Hawaii and Alaska; and dot the states of Wyoming, Colorado and New Mexico.

\section{REGIONAL PENETRATION AND PERFORMANCE OF NONPRIME LOANS}

The proliferation of nonprime mortgages has been a salient feature of the recent housing cycle. Nonprime mortgages are loans that for a number of reasons are considered more risky than traditional prime loans. ${ }^{5}$ This risk may be in the form of the loan's large size or nontraditional structure, or from borrowers who have a poorer credit rating, a higher ratio of debt to income, who do not provide full documentation of income and assets, or are borrowing close to (or over) the value of the property on which the loan is based.

As the economy and the housing market weakened at the end of 2006, a significant share of nonprime mortgages began to perform relatively poorly, particularly those originated between 2005-2007, resulting in rising delinquencies and foreclosures (Haughwout, Peach, and Tracy 2008). The relationship between nonprime lending activity, loan performance, and housing market dynamics at the regional level is a critically important facet to assessing regional housing market performance during the recent cycle. We next examine the prevalence and performance of nonprime loans across metropolitan areas, including upstate New York, and look at the extent to which these were related to metropolitan area housing market dynamics.

To measure nonprime lending activity across metropolitan areas, we utilize First American CoreLogic's LoanPerformance data set (LP Data). As of mid-2009, these data

5 Nonprime loans consist of subprime and alt-A loans. Compared to prime loans, subprime loans are typically of smaller value and made to borrowers with an imperfect credit history, while alt-A loans are typically larger value loans made to borrowers who may choose not to provide full documentation of income or assets typically required to obtain prime mortgages. 
include monthly loan-level information for nearly 5 million active, securitized nonprime loans with total balances of more than $\$ 1$ trillion. While the LP data capture more than 90 percent of securitized nonprime loans after 1999 and nearly all such loans beginning in 2003, all loans held in bank portfolios are excluded (Mayer and Pence 2008). Nonetheless, these data capture the majority of nonprime lending activity and offer valuable insights in the pattern of nonprime lending activity and performance across the country.

\section{A. Penetration of Nonprime Loans}

As a measure of the prevalence of nonprime lending across metropolitan areas, we calculate the number of nonprime loans per 1,000 housing units, utilizing data from 2006 when nonprime lending activity was at its peak. ${ }^{6}$ This metric captures the extent to which nonprime lending activity penetrates into the overall housing market. The first column of Table 2 shows the penetration on nonprime loans in the U.S. overall, by the four boom-bust groupings described previously, and for the individual metropolitan areas located in upstate New York. Nonprime lending activity was much lower in upstate New York than for the nation as a whole. The number of such loans per 1,000 housing units was 55.5 for the U.S., and was less than half this rate for most of upstate’s metropolitan areas. Within upstate New York, nonprime penetration was highest in Albany and Glens Falls, and lowest in Ithaca. With a penetration of 81.6 loans per 1,000 households, it is clear that nonprime lending activity was strongest in the metropolitan areas previously

\footnotetext{
$6 \quad$ To avoid double counting multiple loans related to the same property, the number of loans we report represent first-lien loans only. While the LP data include information on subordinate-lien loans, it is not possible to match these loans to their corresponding first-lien loans. To assess nonprime penetration, we utilize information on total housing units published by the U.S. Census Bureau's population estimates program (available at http://www.census.gov/popest/estimates.html).
} 
identified as “Boom, Bust” places. By contrast, with a penetration rate of 47.0, nonprime lending activity was lowest in metropolitan areas classified as "Modest or No Boom, No Bust” places.

These patterns of nonprime loan penetration suggest that places where there was more nonprime lending activity would have had stronger home price appreciation through the housing peak, coupled with more significant price declines during the period that followed. To assess more formally whether this correlation holds, we plot nonprime penetration relative to the increase in home prices between 2000 and 2006 for every metropolitan area (Panel A of Chart 5). The scatter plot clearly shows a positive and statistically significant correlation between the penetration of nonprime lending activity and house price appreciation during this period.

Why might this correlation hold? It is likely that causation runs in both directions - an increase in nonprime lending led to more significant home price appreciation, and more rapid home price appreciation led to an increase in nonprime lending. In terms of the first, the availability of nonprime loans increased the supply of credit by providing financing opportunities to those unable to obtain prime mortgages. This, in turn, brought more buyers into the housing market, increasing the demand for housing and thereby increasing home prices. On the other hand, home price appreciation itself may have been a cause of an increase in nonprime lending. This can happen because lenders may be more willing to make loans for properties whose value is increasing and is expected to continue to rise, especially when increases are rapid. Under these circumstances, loans on properties with rising values appear less risky. One of the primary determinants of risk from the lender's perspective is the balance of the loan 
relative to the value of the property, often referred to as the "loan-to-value ratio," or LTV. As the value of a home rises, the LTV falls, and a lower LTV loan is considered to be of lower risk than a higher LTV loan. This is because a borrower is less likely to default on a lower LTV loan, primarily because there is more to lose since any equity is potentially surrendered upon default. Even if a default were to occur, a rising home value provides a valuable cushion to mitigate any potential losses the lender may incur when taking possession of a property after a loan fails. Moreover, households experiencing rapid house price appreciation may be more likely to refinance their mortgages in an effort to gain access to the equity in their homes.

Indeed, recent empirical research confirms that the relationship between nonprime lending and house price appreciation has run in both directions. Mian and Sufi (2009) show that the expansion of credit via nonprime lending resulted in more rapid home price appreciation at the zip code level, while Wheaton and Nechayev (2008) and Goetzmann, Peng, and Yen (2009) show that metropolitan areas with faster home price growth saw greater demand for nonprime mortgages. However, because these relationships are selfreinforcing, it is difficult to determine the extent to which these different dynamics were at work or the relative importance of each in contributing to the pattern of house prices observed during the current cycle.

In any event, it is clear that nonprime lending activity was positively correlated with home price appreciation up through the peak in housing activity, and it is also apparent that places with higher penetration of nonprime loans in 2006 had more significant price declines in the 2006-2008 period (Panel B of Chart 5). This correlation is not surprising given that price appreciation in the 2000-2006 period is negatively 
correlated with price appreciation in the 2006-2008 period. The relatively poor performance of nonprime loans during the recession was a likely contributor to this dynamic. To study these relationships in more detail, we next examine the performance of nonprime loans across metropolitan areas and in the upstate New York region, and look at the connection between nonprime loan performance and the pattern of home price changes.

\section{B. Performance of Nonprime Loans}

To assess the performance of nonprime loans at the metropolitan area level, we calculate current delinquency and foreclosure rates. ${ }^{7}$ We measure delinquencies as loans that are 90 or more days past due, and measure foreclosures as loans that have entered the foreclosure process. As expected, the performance of nonprime loans systematically differs across metropolitan areas (Table 2). The highest delinquency and foreclosure rates on nonprime loans are in the "Boom, Bust" and "Modest or No Boom, Bust" metropolitan areas, and the lowest rates are in the groups that did not experience a housing bust.

In general, metropolitan areas with more significant declines in home prices tended to have worse nonprime loan performance (Chart 6). A negative and statistically significant correlation between the average annual change in home prices in the 20062008 period and nonprime foreclosure rates is apparent. There are several reasons for this correlation. First, homeowner equity tended to fall where home prices declined. As previously outlined in the reverse direction, falling house prices in places that experienced a housing bust raised LTVs and increased the risk of default and foreclosure.

7 The LP data we analyze to assess nonprime loan performance are as of August 2009. 
In extreme cases, home prices can decline so much that homeowners fall into a negative equity position, where the balance on a mortgage exceeds the value of the home, providing a strong incentive for a borrower to walk away from a mortgage rather than continue to make payments. Indeed, recent estimates suggest that as many as 29 percent of all nonprime mortgages were in a negative equity position by the end of 2008 (Haughwout and Okah, 2009). This dynamic was probably most visible in "Boom, Bust" metropolitan areas like California, where price declines were among the most severe. Further, poorer loan performance may be the result of the recession reducing the ability of households to repay their debt, for example, in places like in Michigan where unemployment rates are high. Poor loan performance, especially when leading to foreclosure sales, coupled with recessionary pressures, tend to dampen housing prices. This dynamic most likely played a role in "Modest or No Boom, Bust" metropolitan areas like Detroit. In any case, these mechanisms tend to reinforce one another.

As might be expected, in upstate New York’s housing markets, delinquencies and foreclosures on nonprime loans were less severe than the U.S. average, and in many instances, significantly lower. As Table 2 shows, the delinquency rate for the U.S. was 13.2 percent compared to a high of 12.3 percent in Albany and a low of 9.4 percent in Elmira. Similarly, the foreclosure rate for the U.S. was 12.6 percent, with upstate metropolitan areas ranging from 12.0 percent in Albany to 6.5 percent in Buffalo and Ithaca. As was the case for nonprime loan penetration, Albany and Glens Falls stand out among upstate New York's metropolitan areas as being closer to U.S. figures. Delinquency and foreclosure rates in these regions were near the national averages, 
suggesting that nonprime loans were more risky in these metropolitan areas than was typical across upstate New York.

Because of the combination of lower nonprime loan penetration coupled with lower delinquency and foreclosure rates, upstate New York has been less affected than average by the more distressing aspects of the nonprime mortgage market. As a measure of how much the region has been affected by foreclosures, we calculate the number of foreclosures per 1,000 housing units (Table 2). This metric measures how much nonprime delinquencies and foreclosures penetrate into the region's population and housing market. Nonprime delinquencies and foreclosures have affected a smaller share of the housing market in upstate New York than nationwide. Delinquency and foreclosure penetration rates in upstate New York is less than half of that observed nationally, and less than one-third of that observed in the "Boom, Bust" metropolitan areas. This pattern of relatively low nonprime loan penetration, coupled with relatively better nonprime loan performance, helps explain the stability of the region's housing market during the recession.

\section{CONCLUSIONS}

During the past decade, the United States experienced a significant boom and bust in residential real estate activity. By contrast, the housing markets in upstate New York remained relatively stable throughout this entire period. Indeed, since the housing market decline that began in 2006, residential real estate activity in upstate New York has remained relatively flat and home prices have continued to rise into 2009. During the housing boom years of 2000-2006, home prices in Binghamton, Buffalo, Elmira, Rochester, Syracuse, and Utica did not appreciate as rapidly as the national average, 
while prices in Albany, Glens Falls, and Ithaca, all outperformed the nation. Since then, home prices have risen faster (or fallen more slowly) than the nation in every upstate metropolitan area.

One factor that likely played a role in amplifying the boom-bust real estate cycle in many parts of the country was the prevalence of nonprime mortgages. Metropolitan areas with a higher penetration of these loans by 2006 - when such activity was at its peak - experienced faster home price appreciation along the way, but also experienced a relatively rapid decline in values once the reversal began. As a result, a larger number of the nonprime loans originated in these places have entered into delinquency or foreclosure. The penetration of these relatively riskier loans in upstate New York was far less than what was experienced in other parts of the country, particularly when compared to metropolitan areas that experienced a housing bust. Moreover, these loans have performed better in upstate New York than nationally. These patterns of nonprime lending activity have contributed to the stability of upstate New York's housing markets during the current recession. 


\section{REFERENCES}

Calhoun, Charles A. 1996. "OFHEO House Price Indexes: HPI Technical Description,” Office of Federal Housing Enterprise Oversight Research Paper, March.

Goetzmann, William N., Liang Peng, and Jacqueline Yen. 2009. “The Subprime Crisis and House Price Appreciation,” NBER Working Paper No. 15334, September.

Haughwout, Andrew F. and Ebiere Okah. 2009. "Below the Line: Estimates of Negative Equity Among Nonprime Mortgage Borrowers,” Federal Reserve Bank of New York Economic Policy Review, Vol. 15, No. 1, pp. 31-43.

Haughwout, Andrew F., Richard Peach, and Joseph Tracy. 2008. "Juvenile Delinquent Mortgages: Bad Credit or Bad Economy?” Journal of Urban Economics, Vol. 64, No. 2, pp. 246-57.

Leventis, Andrew. 2008. "Revisiting the Differences between the OFHEO and S\&P/Case-Shiller House Price Indexes: New Explanations,” Office of Federal Housing Enterprise Oversight Research Paper, January.

Mayer, Christopher and Karen Pence. 2008. "Subprime Mortgages: What, Where, and to Whom?” Board of Governors of the Federal Reserve System Finance and Economics Discussion Series Working Paper No. 2008-29, June.

Mian, Atif and Amir Sufi. 2009. "The Consequences of Mortgage Credit Expansion: Evidence from the 2007 Mortgage Default Crisis," Quarterly Journal of Economics, Vol. 124, No. 4 (November). 
Wheaton, William C. and Gleb Nechayev. 2008. “The 1998-2005 Housing 'Bubble’ and the Current 'Correction': What's Different This Time?” Journal of Real Estate Research, Vol. 30, No. 1, pp. 1-26. 


\section{Chart 1: Existing Single-Family Home Sales}

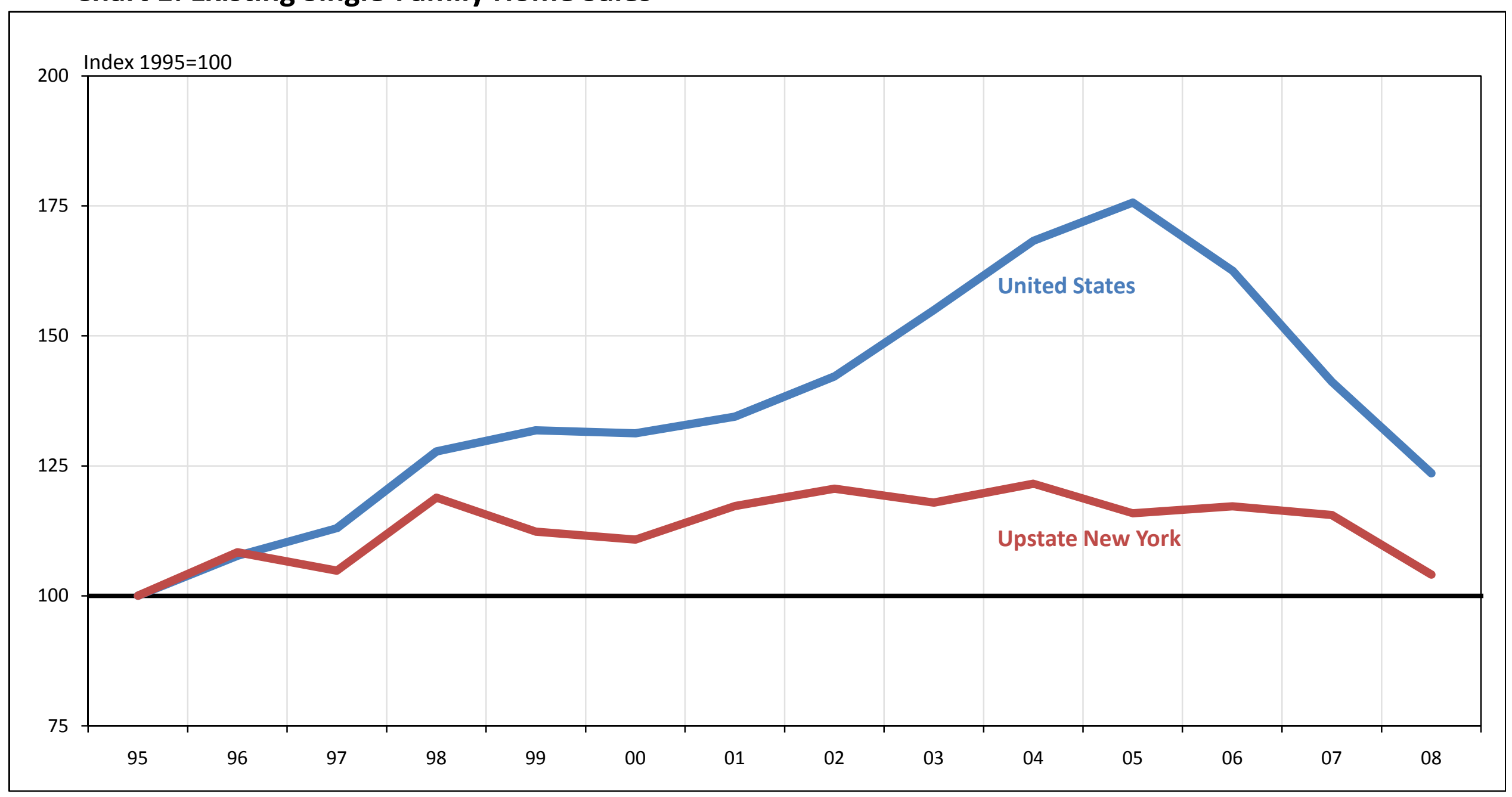

Note: Upstate New York is an aggregate of the Albany, Buffalo, Rochester, Syracuse, Utica, Binghamton, Ithaca, Elmira, and Glens Falls MSAs.

Sources: National Association of Realtors; Moody's Economy.com estimates 


\section{Chart 2: Single-Family Building Permits Per Capita}

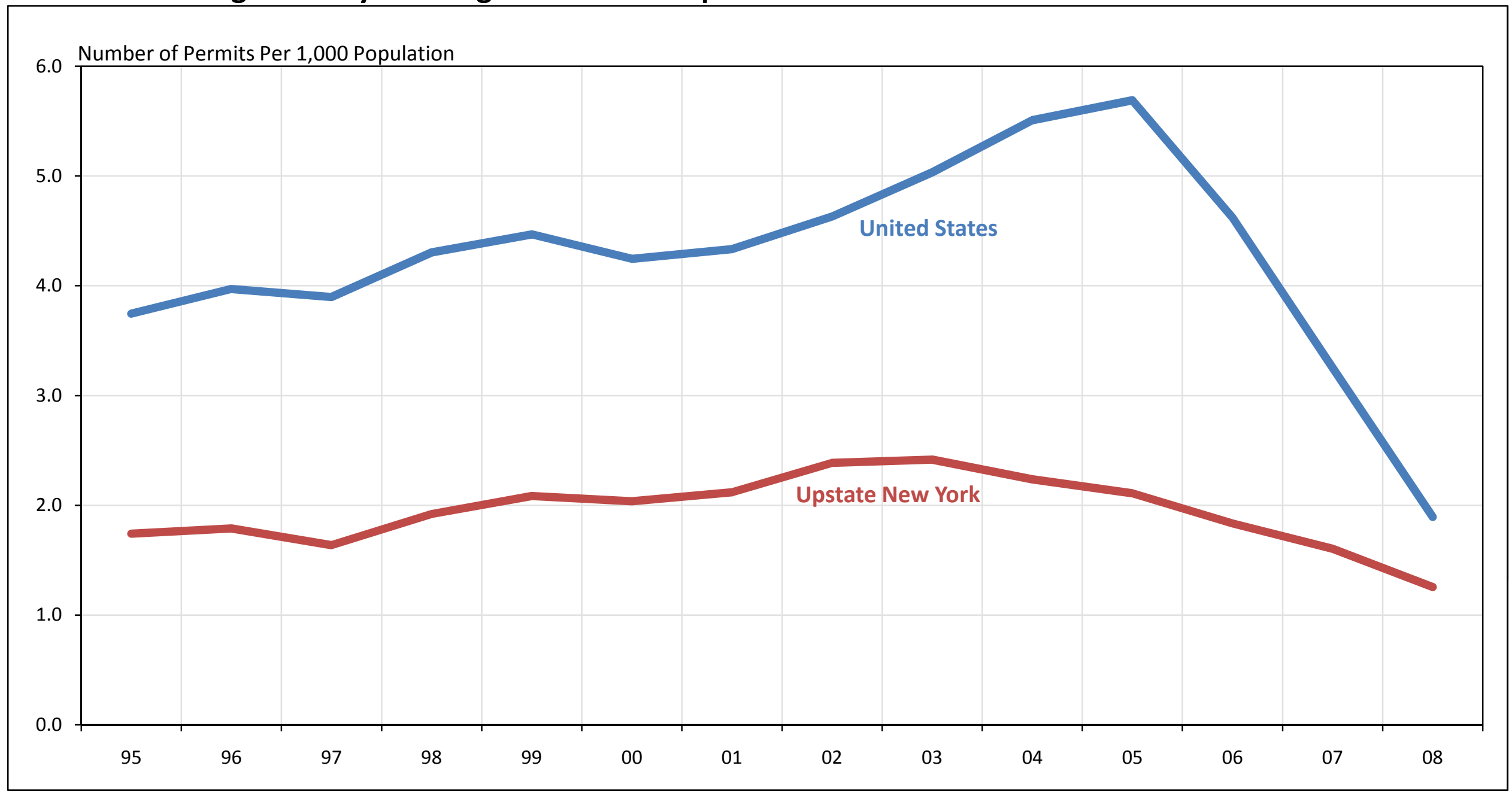

Note: Upstate New York is an aggregate of the Albany, Buffalo, Rochester, Syracuse, Utica, Binghamton, Ithaca, Elmira, and Glens Falls MSAs.

Sources: U.S. Census Bureau; Moody's Economy.com 


\section{Chart 3: Change in Home Prices}

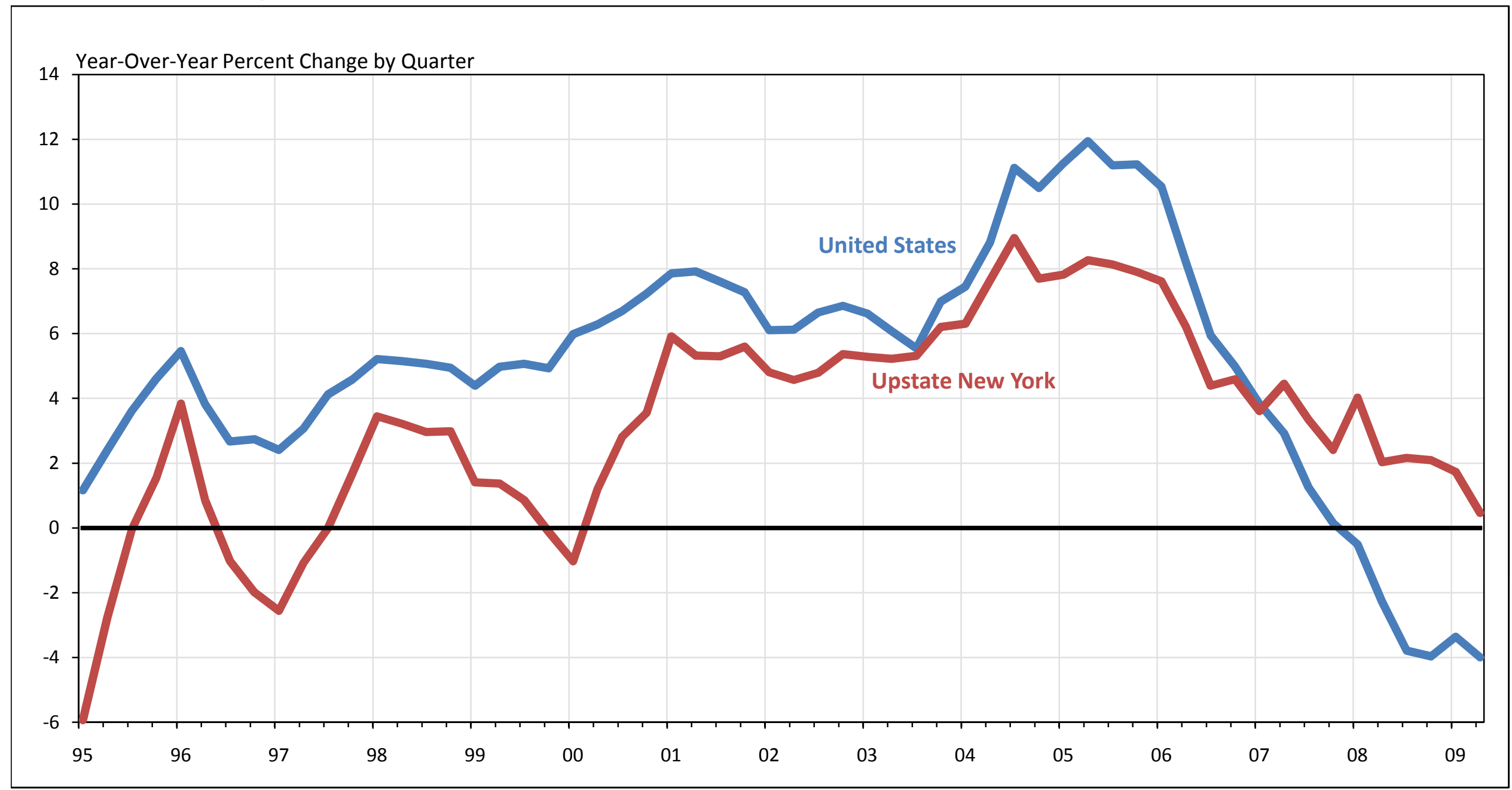

Note: Upstate New York is an aggregate of the Albany, Buffalo, Rochester, Syracuse, Utica, Binghamton, Ithaca, Elmira, and Glens Falls MSAs.

Upstate was aggregated using housing unit weights in a process similar to that employed by FHFA for creating their United States index.

Sources: Federal Housing Finance Agency (All Transactions Index); U.S. Census Bureau; Moody's Economy.com; Authors' Calculations 
Chart 4: Home Price Appreciation 2000 to 2008

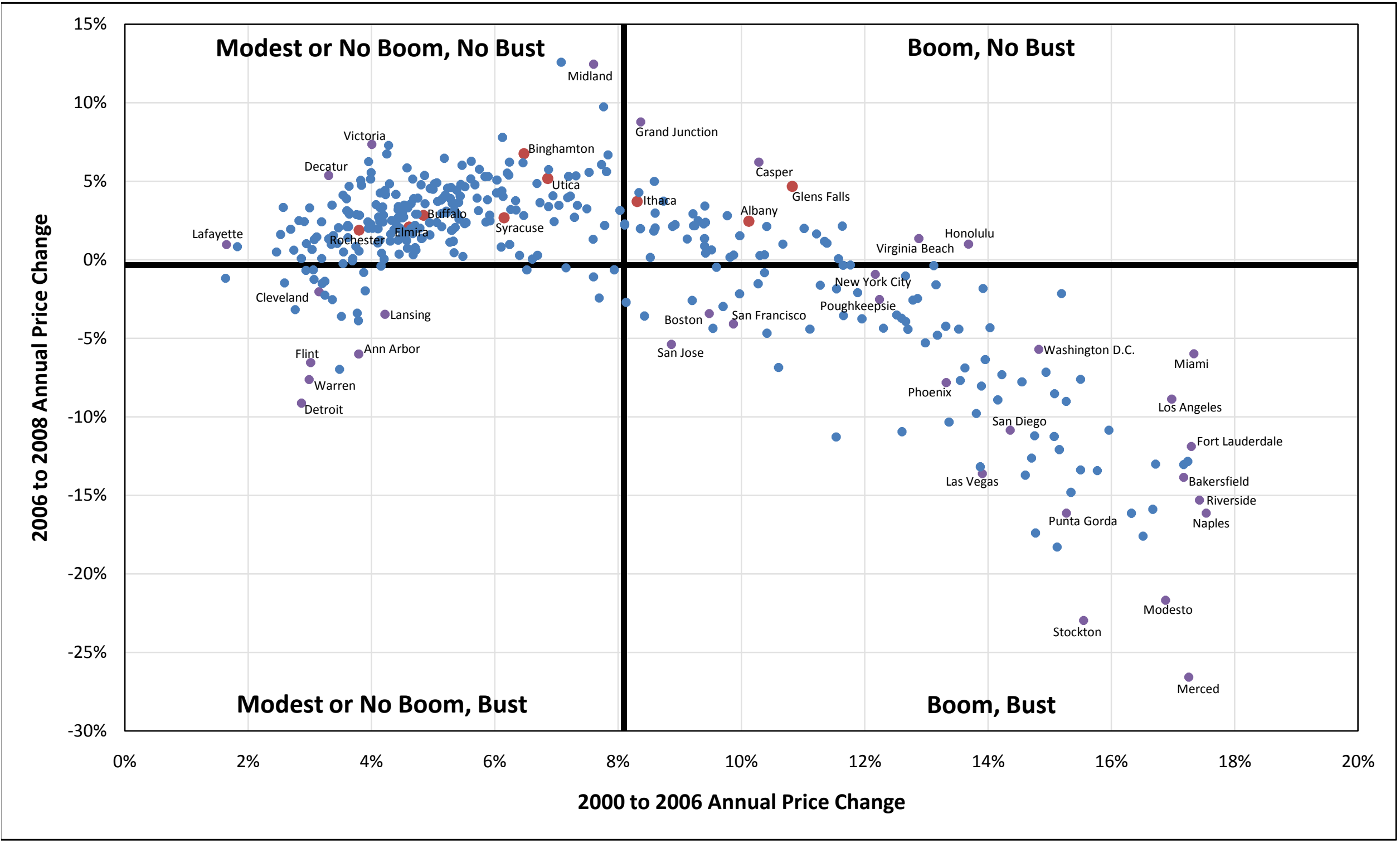

Sources: Federal Housing Finance Agency (All Transactions Index); Moody's Economy.com 
Chart 5: Nonprime Loan Penetration and Home Price Changes

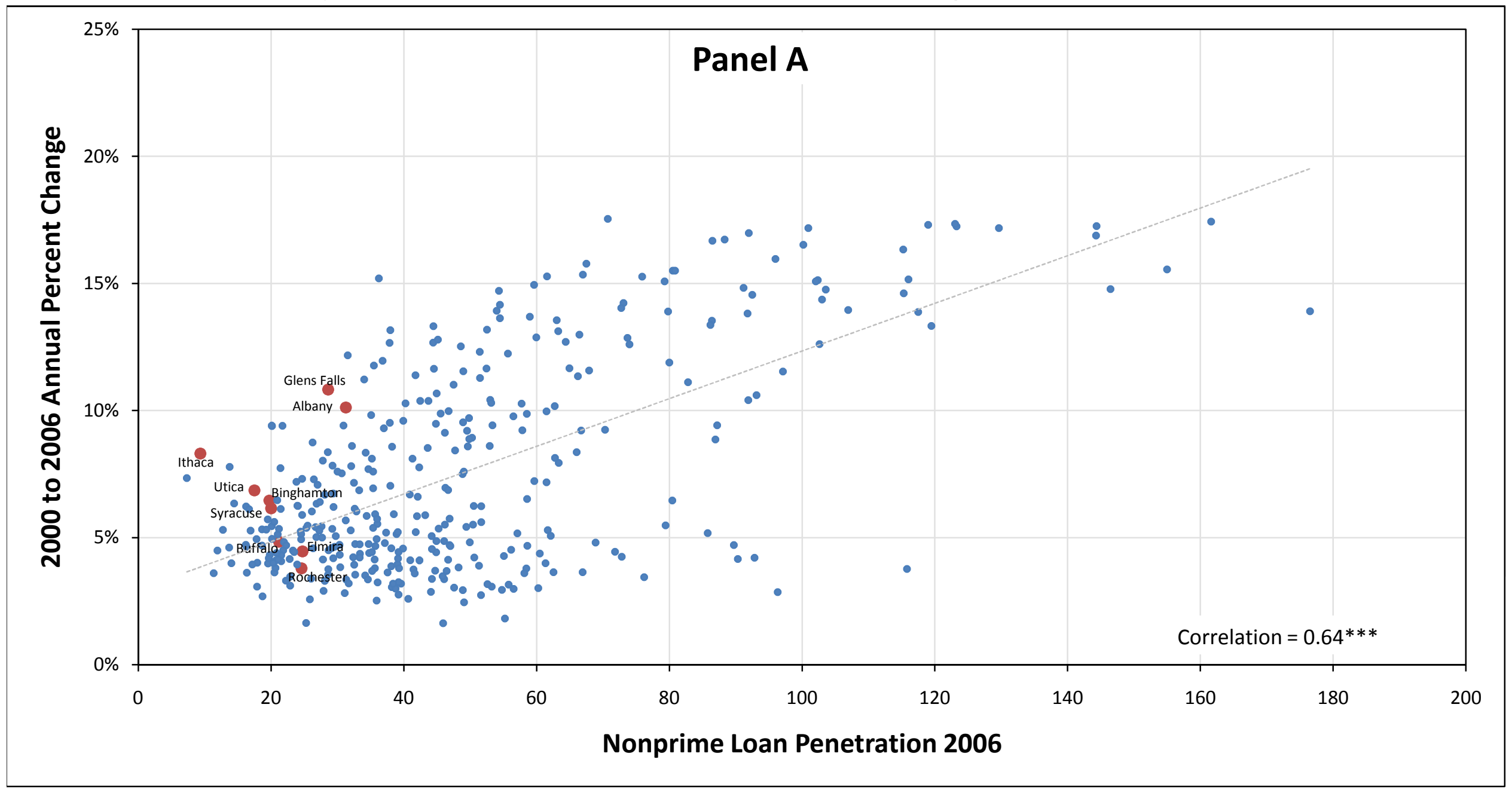

Notes: ${ }^{* *}$ indicates statistically significant at the .01 level. Loan penetration is the number of nonprime loans per 1,000 housing units.

Sources: FirstAmerican CoreLogic, Loan Performance Data; Federal Housing Finance Agency (All Transactions Index);

U.S. Census Bureau; Moody's Economy.com 


\section{Chart 5: Nonprime Loan Penetration and Home Price Changes}

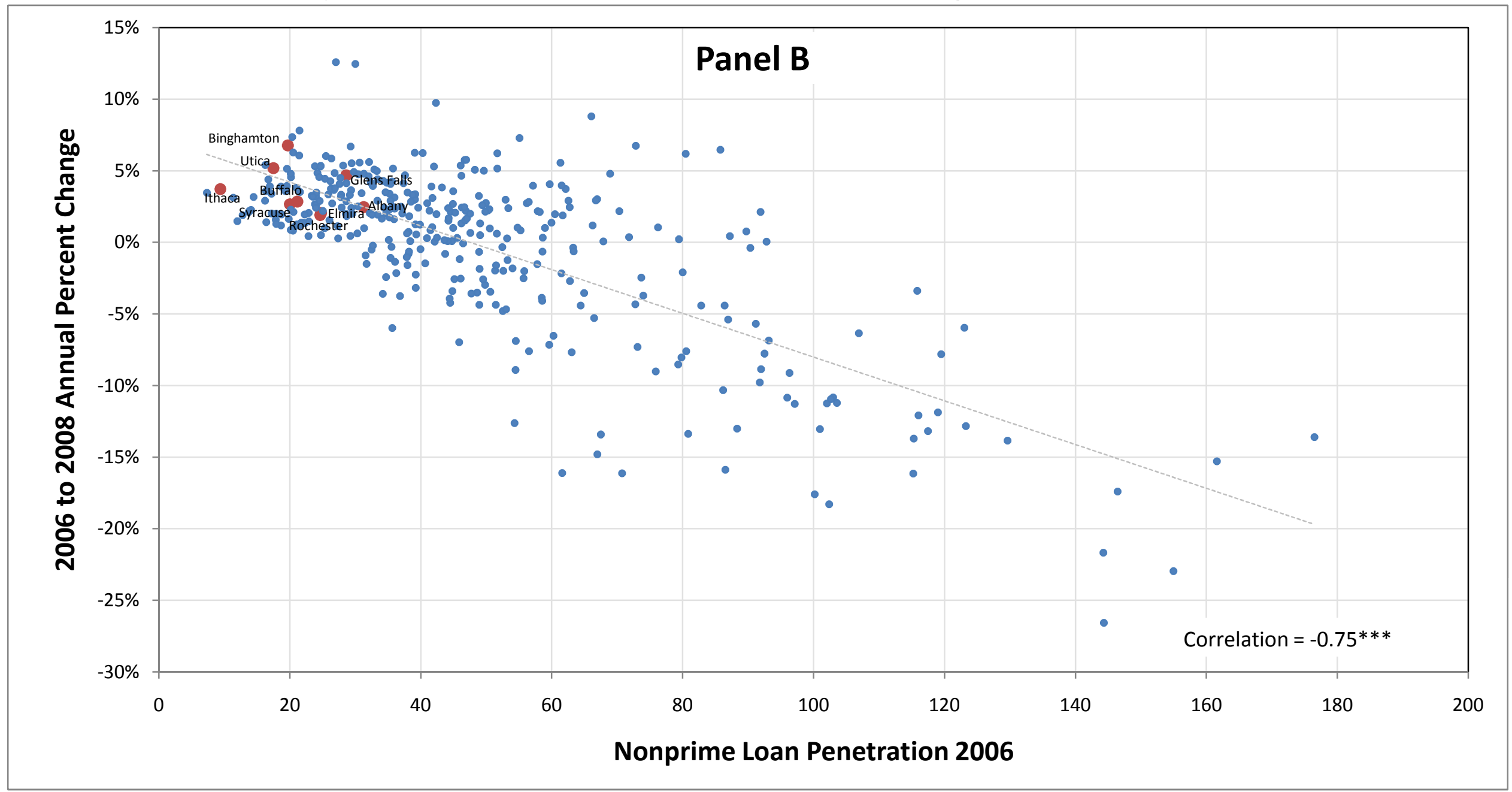

Notes: ${ }^{* * *}$ indicates statistically significant at the .01 level. Loan penetration is the number of nonprime loans per 1,000 housing units.

Sources: FirstAmerican CoreLogic, Loan Performance Data; Federal Housing Finance Agency (All Transactions Index);

U.S. Census Bureau; Moody's Economy.com 


\section{Chart 6: Foreclosure Rates and Home Price Changes}

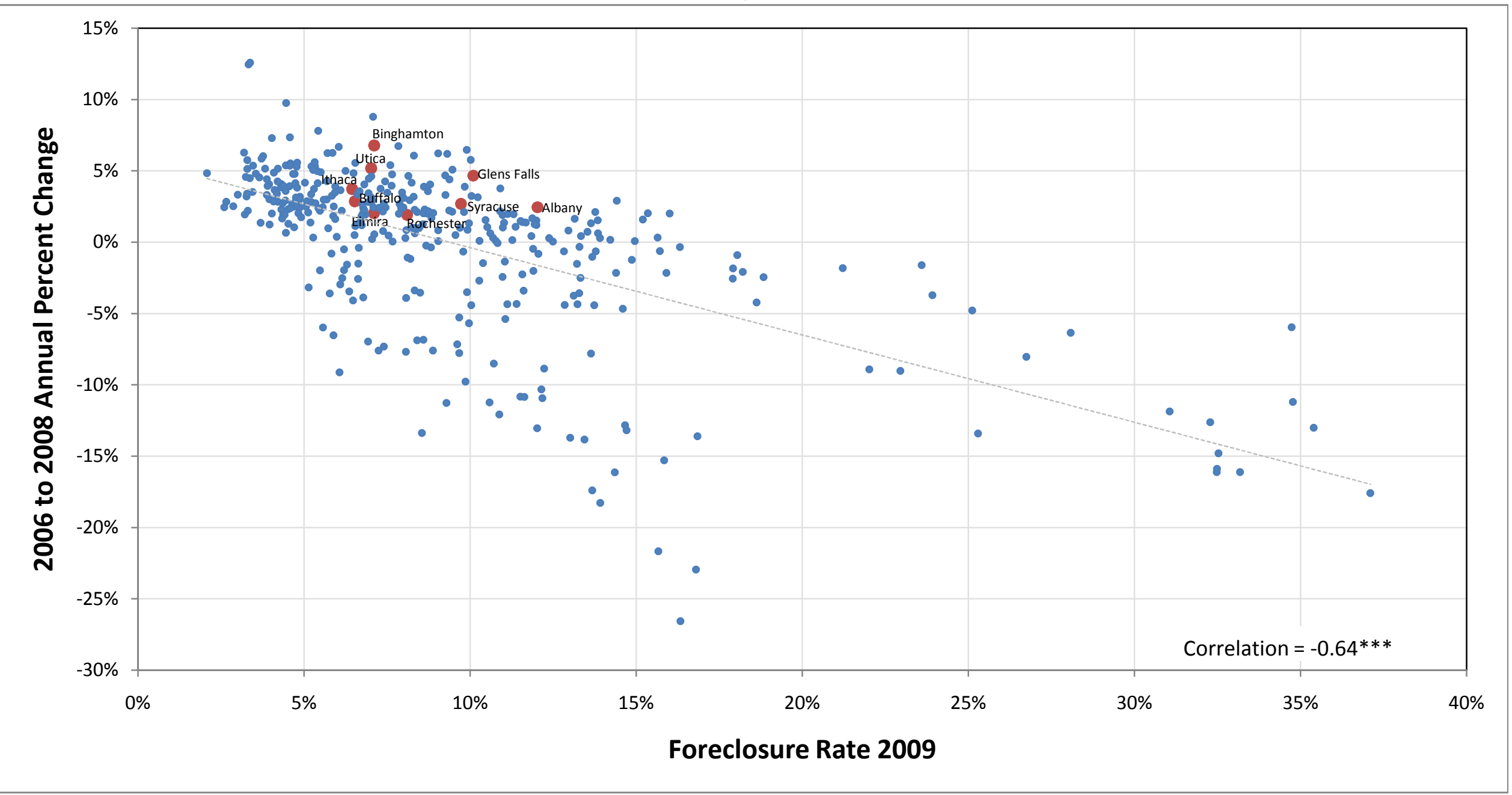

Note: $* * *$ indicates statistically significant at the .01 level.

Sources: FirstAmerican CoreLogic, Loan Performance Data; Federal Housing Finance Agency (All Transactions Index); Moody's Economy.com 
Table 1: Annual Percent Change in Home Prices

\begin{tabular}{|c|c|c|c|}
\hline Geography & $\begin{array}{c}2000 \\
\text { to } \\
2006 \\
\end{array}$ & $\begin{array}{c}2006 \\
\text { to } \\
2008 \\
\end{array}$ & $\begin{array}{c}2008 \mathrm{H} 1 \\
\text { to } \\
2009 \mathrm{H} 1 \\
\end{array}$ \\
\hline United States & $8.1 \%$ & $-0.3 \%$ & $-3.7 \%$ \\
\hline \multicolumn{4}{|l|}{ Upstate Metros: } \\
\hline Glens Falls & $10.8 \%$ & $4.7 \%$ & $-1.3 \%$ \\
\hline Albany & $10.1 \%$ & $2.5 \%$ & $-1.0 \%$ \\
\hline Ithaca & $8.3 \%$ & $3.7 \%$ & $-0.4 \%$ \\
\hline Utica & $6.9 \%$ & $5.2 \%$ & $0.7 \%$ \\
\hline Binghamton & $6.5 \%$ & $6.8 \%$ & $1.8 \%$ \\
\hline Syracuse & $6.2 \%$ & $2.7 \%$ & $1.0 \%$ \\
\hline Buffalo & $4.8 \%$ & $2.8 \%$ & $2.3 \%$ \\
\hline Elmira & $4.5 \%$ & $2.0 \%$ & $6.0 \%$ \\
\hline Rochester & $3.8 \%$ & $1.9 \%$ & $1.4 \%$ \\
\hline
\end{tabular}

Note: $2008 \mathrm{H} 1$ and $2009 \mathrm{H} 1$ refers to an average of the first two quarters of the year.

Sources: Federal Housing Finance Agency (All Transactions Index); Moody's Economy.com 
Table 2: Nonprime Loan Penetration and Performance

\begin{tabular}{|c|c|c|c|c|c|}
\hline \multirow[b]{2}{*}{ Geography } & 2006 & \multicolumn{4}{|c|}{2009} \\
\hline & $\begin{array}{r}\text { Nonprime Loan } \\
\text { Penetration }\end{array}$ & $\begin{array}{r}\text { Delinquency } \\
\text { Rate }\end{array}$ & $\begin{array}{r}\text { Foreclosure } \\
\text { Rate }\end{array}$ & $\begin{array}{l}\text { Delinquency } \\
\text { Penetration }\end{array}$ & $\begin{array}{l}\text { Foreclosure } \\
\text { Penetration }\end{array}$ \\
\hline United States & 55.5 & $13.2 \%$ & $12.6 \%$ & 5.2 & 5.0 \\
\hline Modest or No Boom, Bust & 58.3 & $15.1 \%$ & $11.3 \%$ & 5.7 & 4.3 \\
\hline Modest or No Boom, No Bust & 47.0 & $11.9 \%$ & $6.8 \%$ & 3.7 & 2.1 \\
\hline Boom, No Bust & 52.1 & $11.5 \%$ & $8.9 \%$ & 4.2 & 3.2 \\
\hline Boom, Bust & 81.6 & $14.3 \%$ & $17.1 \%$ & 8.8 & 10.5 \\
\hline \multicolumn{6}{|l|}{ Upstate Metros: } \\
\hline Albany & 31.3 & $12.5 \%$ & $12.0 \%$ & 2.8 & 2.7 \\
\hline Glens Falls & 28.6 & $12.5 \%$ & $10.1 \%$ & 2.8 & 2.2 \\
\hline Elmira & 24.7 & $9.4 \%$ & $7.1 \%$ & 1.9 & 1.4 \\
\hline Rochester & 24.6 & $10.7 \%$ & $8.1 \%$ & 2.0 & 1.5 \\
\hline Buffalo & 21.2 & $10.3 \%$ & $6.5 \%$ & 1.7 & 1.1 \\
\hline Syracuse & 20.0 & $11.0 \%$ & $9.7 \%$ & 1.7 & 1.5 \\
\hline Binghamton & 19.7 & $10.5 \%$ & $7.1 \%$ & 1.7 & 1.1 \\
\hline Utica & 17.5 & $11.2 \%$ & $7.0 \%$ & 1.6 & 1.0 \\
\hline Ithaca & 9.4 & $11.5 \%$ & $6.5 \%$ & 0.8 & 0.4 \\
\hline
\end{tabular}

Notes: Penetration measures the number of loans in each category per 1,000 housing units. Rate measures the number of loans in each category as a percentage of total nonprime loans.

Sources: FirstAmerican CoreLogic, Loan Performance Data; U.S. Bureau of the Census 
Map: Geographic Distribution of Boom/Bust Metropolitan Areas

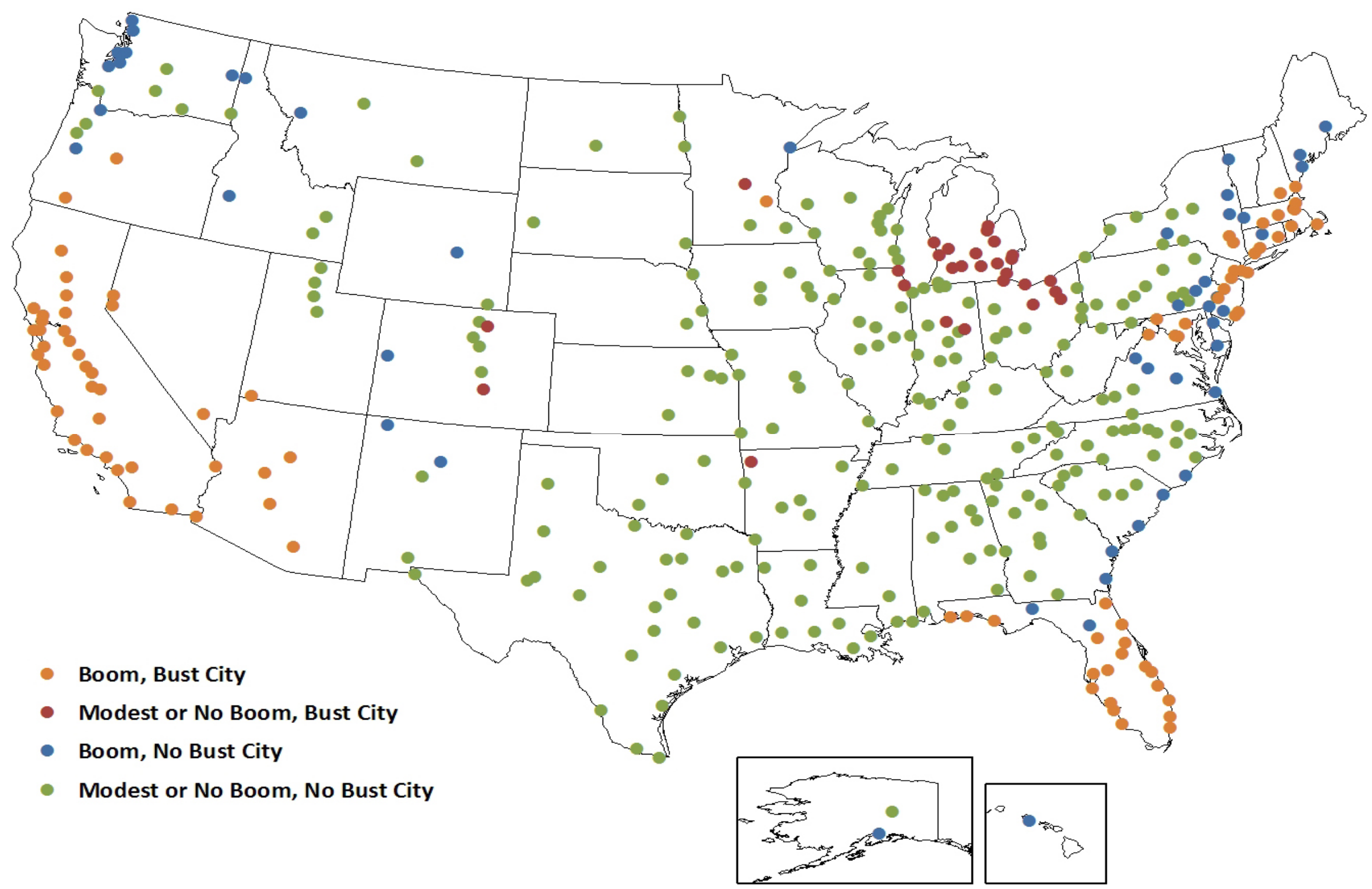

